5. Piṣtapura, Mahendragiri, and King Achyuta.

$$
\begin{aligned}
& \text { Gorakhpur, } \\
& \qquad \text { May } 9,1897 .
\end{aligned}
$$

Dear Professor Rhys Davids, - Though pleased to learn, from the correspondence in the April number of the Journal, that my article on Samudra Gupta has attracted the attention of such competent scholars as Messrs. Sewell and Rapson, I must ask permission to point out that my rather rash procedure in publishing my conclusions in advance of the evidence for them has done me injustice. The dissertation on the "Conquests of Samudra Gupta," now on its way to England, will, I hope, convince Mr. Sewell that my interpretation of the name Mahendragiri is correct.

The same paper gives a full account of the coins which Mr. Rapson agrees with me in ascribing to the king Achyuta, who was conquered by Samudra Gupta.

I am gratified to find that Mr. Rapson and myself have independently arrived at the same conclusion concerning the correct attribution of the Achyu coins. Those coins are, as Mr. Rapson rightly observes, closely allied to the better known coins of the Nägas.

Another group of coins allied to the Nāga issues is that of the Málava coins, recently described in detail by Mr. Rodgers. ${ }^{1}$ In fact, a few of the coins placed in the Mălava series by Mr. Rodgers (Nos. 12,461 to 12,465) are probably Nāga rather than Mālava. The Mālava coins are likewise closely related to the "vase type" of Candra, which I now attribute with confidence to Candra Gupta II, the Candra of the Iron Pillar.

\title{
Vincent Smith.
}

1 "Catalogue of the Coins of the Indian Museum," part iii, pp. 15-27. The coins deseribed are from the great hoard of 6,000 obtained by $\mathbf{M r}$. Carlleyle at Nagar in the Jaipur State (" Reports," vi, 165, 173-183). 